\title{
Probe into the Long-term Mechanism of "Studio Model" Teaching Internal Quality Guarantee
}

\author{
Yong Zhang ${ }^{1, \mathrm{a}}$, Yingying Shao ${ }^{1}$ and Hongjie $\mathrm{Yu}^{1}$ \\ ${ }^{1}$ Liaoning Shihua University, School of Art and Design, 113001 Fushun, China
}

\begin{abstract}
Under the background of mass entrepreneurship and innovation, improving the quality of the teaching results and accomplishing the conversion of teaching achievements are the changes for the reform and development of colleges and universities. The reform of "Studio Model" teaching is more conducive to the improvement of undergraduate teaching quality, converse to results orientation. The effective quality guarantee mechanism is the important guarantee for forming undergraduate teaching method reform. Through the discussion of the concept and method of Carnegie Mellon University and the colleges of China. This paper puts forward the teaching reformation and exploration of the "Studio Model", Based on the idea of implementing the "effective teaching", this paper constructs the results-oriented curriculum in a pragmatic and innovative way, designs the teaching with the design competition and the practice project as the motivation.
\end{abstract}

\section{Introduction}

In classes of design, the "Studio Model" teaching is more conducive to have further study of complex problems and improve the knowledge, ability and quality of college students. At present, it has become an important direction of the teaching reformation of college design. The Studio Model is different from the traditional teaching mode, and the form is more conductive to have free and open. Whether traditional system management or the reformation of advanced innovation model, the aim is to guarantee the quality of teaching. Therefore, how to guarantee internal quality of reformation of teaching mode, and establish a long term mechanism for innovation of teaching model has become the most important reformation of studio teaching model.

\section{Practice the concept of "Effective Teaching" in school}

"Effective Teaching" is a teaching concept which was developed in the 1960s. The main figure is Benjamin Bloom, an American educational psychologist who believes that "Effective Teaching begins by knowing exactly what you want to achieve" [1]. The core of effective teaching concept is to pay attention to the needs, growth and development of students. The University of Carnegie Mellon has always used effective teaching as an important aspect of undergraduate education. In 1982, it established the, Aiboli Centre for Excellence in Teaching and Educational Innovation, to provide necessary guidance and support for effective "Teaching" and "Learning" [2]. The "Effective
Teaching" has significant meaning of guiding in school, more conveniently and effectively. The rapid development of information technology and media makes the access to information more convenient and effective, the traditional classroom model can not meet the needs of the students. The unilateral acquisition of knowledge is so boring that the information received by teachers and students is often duplicated. he students sleep in class, play with their mobile phones in class, and even questions the usefulness and significance of what they are learning. Schools installs indoor cameras, block cell phone signals, and ask teachers to strengthen classroom management. The Office of academic AffairsTeachers-students change the phenomenon from top to bottom in the way of pressure conduction rather than solve the problem. This phenomenon has filled the whole semester. "Credit hours" should be the time for students to study, and the ways to acquire knowledge, it should be diverse. Therefore, the classroom should not become exclusive stage of teachers. Teachers should have good professional teaching skills, The teachers also need to set an example for students, They should as well can fully develop interest and motivation, and promote independent and effective learning for students [2]. Taking Liaoning Shihua University (LSHU for short) as an example, since the establishment of the College of Art and Design in 2015, taking students as the center, training people as the core, combined with the characteristics of regional industry and service local cultural characteristics to determine the "effective teaching" of the orientation and characteristics of the school.Establishing the orientation and characteristics of "effective teaching" to train students,combining regional industry characteristics and Service local culture.

\footnotetext{
*Corresponding author: ${ }^{\text {a } 176978002 @ q q . c o m}$
} 
Professional orientation: to serve the local cultural industry and the development of petrochemical industry as the orientation, the application of undergraduate education is the lead. Combined with the old industrial base in northeast China, the cultural characteristics of the Fushun Manchu and the before Qing Dynasty and nonmaterial cultural heritage of amber and agate, the design of products, environmental art design and visual communication design as the direction of social needs are taught in the professional knowledge of design. Students have the ability to think and solve problems systematically by using the thought of design, focus on harmony and unity from human to product to environment, so as to provide senior personnel for revitalizing the old industrial base, serving the petroleum equipment manufacturing industry and promoting the development of local cultural industry.

Specialty characteristics: Building a "studio model" teaching model for schools and enterprises as a carrier, the using real subjects, with the main direction of petrochemical, equipment manufacturing, transportation equipment, local cultural creative products, agate and amber carving creativity, furniture design, environmental art and visual transmission. We will set up a multi-level team structure of experts and external professionals with advanced academic titles at the core of the workshop, conduct seminars, experiential, practical and exploratory classroom teaching, and initiate collaborative innovation in cooperation cross specialty union, school to school union, school to enterprise union and... through variety ways to train the students to be professionals. Cooperating and innovating inter school, inter school, school to enterprise and international facilities is great to build a new mode of training personnel who can be taught through studying and taught through creation.

\section{Pragmatism and Innovation in Results-based Curriculum Construction}

\subsection{Definition of impact of goals on the results}

"Purpose is that sense that we are part of something bigger than ourselves, that we are needed, that we have something better ahead to work for. Purpose is what creates true happiness." Facebook founder Mark Elliot Zuckerberg said in a 2017 Harvard University speech. Goals have the function of guiding, challenging oneself and strengthening self-confidence, use the result to motivate oneself, better results will be achieved. Enforcement is the ability to transform goals into results. LSHU is in the process of the practical teaching reformation. The principal focuses on teaching management, the dean of School of Art and Design directly manages teaching and organizes all teachers to participate in the revision of the teaching plan, and systematizes the system of subject and the logical relationship between courses. The teachers discuss and revise the teaching syllabus. They also study the content of the curriculum to achieve anticipated results of teaching. The teachers carry out the discussion session of "pre-course presentation and after-school summary", so that teachers can set standards and norms for the design of the class, process control and evaluation of each part of the curriculum. Teachers must be able to understand and control the whole system of professional courses, rather than taking a separate course in the traditional way. Every course is an important of the training plan of the students. creating a cause-and-effect logic that links up and connects. Every course is a causal connection. Only in this way can teachers think, improve and effectively implement their of instruction, focusing on issues that students are willing to learn and teach themselves.

\subsection{Outcome orientation to break the logic of linear thinking}

In the teaching mode of product design, it is emphasized that the program and method of product design are the center of design activities. Linear thinking product design model is suitable for companies and enterprises to manage. Through,design and assign design tasks through the design process, even new employees can successfully complete the task.As for teaching, linear thinking, which is guided by design program, will constraint the cognition of design, and Linear thinking makes students focus on finishing the whole design on schedule [3]. In linear thinking, "brainstorming" is often used in order to improve efficiency to force oneself to find new problems. In the end, it will quickly transform the "problem representation" into "conceptual design", ignoring the "origin" of the design, lacking in-depth study of people's way of life, and failing to solve the problem from a pragmatic and demand perspectively.

I studied School of Design of Dalian Minzu University with my thinking and questions. Their School of Design is one of the most successful departments with "Studio Model". The aim of the course is to move the course forward by providing students with a great deal of time to consult materials and to solve complex problems in practice, such as technology and materials, while teachers and students spend more time in the course than the total number of hours. Finally, through the annual Design Festival, students presented, compared, exchanged and presented with results. The work is surprising.

In the course of the studio education, it is found that because each student has a different professional foundation, according to the same linear thinking product design model, the design results did not break through, even at the end of successive semesters did not change the student's performance, some students' credits have been very high but some students' have been very low. This is a situation that we should think about thoroughly. If the ways and means of solving problems are not the only ones, then how can we break the logic of linear thinking? After thinking thoroughly, we try to design a new task to test the appeal question, which requires solving the problem. The result of the design can not be shown in a virtual way (hand-drawn or computer rendering). It must be an object. When the subject was announced, everyone was in a different situation. The quiet students are thinking of drawing a 
plan. Some active students go to the market for materials. One week later, 17 students submit 17 physical programmes. It is difficult to tell who designed them from the perspective of the programme alone. The task breaks our teachers' former impression of the students. A lot underachievers may impress the teacher. Everyone is confident when they finally show and explain their results, because everyone is doing what they do best.

\subsection{Demand-oriented role shift}

Under the influence of Carnegie Mellon's research university culture, the Aiboli Center for Excellence in Teaching and Educational Innovation focuses on applying the relevant research of "learning science" to teaching practice and advocates "research-oriented" and "data-driven" teaching practice. To encourage teachers to carry out relevant teaching research around the "needs of teaching and learning", so we can improve the quality of teaching and learning [4]. In the research of professional teaching direction studio, we follow the teaching research of "teaching" and "learning". Teaching is led by students and the role of teachers is transformed into guides and managers. As a guide, students demand more of teachers' teaching ability and subject knowledge structure. Teachers must keep pace with times and they also need to have the attitude of continuous learning. set an example for students from the professional perspective, so that teachers can form in front of students with awe, mutual trust and hope. Instead of the traditional way to intensify the conflict, the teaching model of the School of Art Design of LSHU will be detailed. Small classes are formed which contain 15 students. Teachers of studio are responsible for the study and employment of students. Undergraduate education uses tutorial system, which is a way that teachers to teach their students. After students enter the studio to study, we will cancel the old form of class. The new class is the studio. The teacher in charge of the studio is the head teacher. The advantage of dual identity in "Studio Model" is that it can meet the needs of the students in all aspects. From daily life to professional study, this is more conducive to cultivating their personality. School teachers are required to have a talk with each student at least once a month heart-to-heart. From the perspective of studio teaching to team building, teachers have been difficult to separate the dual roles. The activity of heart-to-heart talk has changed into "periodic information feedback". At first students do their own summary first. And then the teachers will give feedback according to the current condition of the students. In the process of communication, students can raise some claim and help the teachers. And teachers and students can plan further for their study through exchange of information. Working indoor advocacy is a part of life, and students should learn to do more meaningful things in limited time. Teachers are in such roles to set an example, encourage each other, competing, form a strong learning atmosphere.

\section{Teaching of Design affected by design competitions and practical projects}

Project design I, project design II and project design III are the three stages in which students learn in a studio. The stages are guided by the overall goal of the program. Professional subjects are designed as carriers to make students' ability to study by themselves, use knowledge to solve practical problems and the ability of communication. Project Design I, Project Design II and Project Design III span fifth, sixth and seventh semesters. It is a continuous process of continuous progression and progressive improvement. Through the classical design reproduction, Project Design I enhance the ability of the students' basic form, improve their aesthetic and modeling ability with line extraction and feature expression, and finally express the design theme accurately. Project Design II is to design competition to be a standard. It can broaden their minds. It can limit the subject. It makes the students to concentrate better. It makes students innovate and gives them the courage to challenge. To make students master the main parts of knowledge, the students learn in practice. Train them have better ability of thinking analysis. So that students form a model of scientific design thinking. Car Design Awards of China is the most important car design event in China. The design mission is written by worldrenowned automotive OEM. The competition judges are composed of design directors from famous auto companies. It creates great opportunity for student designers to win an authoritative award and embark on a career in automotive design [5]. Transportation and Large Equipment studio in 2017 were nominated in Car Design Awards of China(CDN for short). Liaoning Shihua University was at the tenth place along with Beijing Institute of Technology, Hubei Institute of Fine Arts and Jiangsu University. In 2018, in the ninth Car Design Awards of China, five pieces of work were nominated and it was one of the most nominated universities. Our course does not participate the competition blindly or the it has utilitarian purpose. But to grasp the design of evaluation standard through international design platform. It's also for keeping the education ideas and methods of advanced and authority.

The main goal of Project Design III is to train students to study comprehensive subjects from the design standardization operation ability. On the basis of the theory of product innovation and design people focus on the social hot spots, pain points, interests, and the focus of the government concerned, the relationship between human and things, in comprehensive and systematic way to solve more complex problems. Through the social problem investigation, further study of creative solutions to complex problems and put forward comprehensive, design for the graduation and employment.

Case 1: ocean ball cleaning machine design project. Ocean ball is indoor amusement park covers an area of the larger a way of amusement, its numerous manual cleaning is difficult. It is a good way of getting ready for Graduation Thesis. Through the development of ocean 
ball cleaning equipment at home and abroad the analysis of the current situation and market demand, product research and development mode of "original design" has begun. Research as the theoretical basis, ensure Marine ball cleaning effect and the efficiency is the premise, developing the ocean ball cleaning machine design and prototype experimental study, at present it has already completed three prototype design iteration.

Case 2: Parent-Child Chair design project. The traditional children's dining chair is specially designed for children, which is limited by the size of the structure and the rapid growth of children. Traditional children dining chair function is single, easy to eliminate. In order to solve the above problem, we designed a dual-purpose chair, aimed at children eat chair design into the double purpose of chairs, two functions are implemented by reverse positive and opposite, one end is children eat chair, chair at the other end is adult. Parent-Child Chair won the 2017A' Design Award silver Award and 2017 China Red Star Original Design Award, which has achieved the transformation and production of the product, and the whole teaching process is to advocate" to work with creativity and to start a business with achievements ".

\section{Conclusion}

Studio pattern breaks the traditional mode of classroom teaching. The classroom teaching of "Studio Model" has cultivated the students subjective consciousness. Carrying out classroom teaching raises the students subjective consciousness. The mode of classroom teaching is discussion, experiential, practical, exploratory and open. Today, under the background of mass entrepreneurship and innovation, it is of great importance to cultivate the subject consciousness of designers [6]. The School of Art and Design of LSHU has carried out the "Studio Model" for three years, which is now beginning to take shape, but also ushered in the bottleneck period of reformation and innovation promotion. Only to the "studio" mode teaching continuously explore, the mechanism of internal quality assurance and research, we can promote the curriculum reform and improving the quality of student learning. In the whole process of implement and carry out only when the teacher is willing and active participation truly meaningful. Give full play to teachers' professional practice of the concept of "effective teaching", students' learning results of design, evaluation and application of enthusiasm, promoting undergraduate teaching quality has a long way to go [2].

\section{References}

1. M.X. Shan, Investigation and analysis of effective instruction in American Higher Educational Institution: Taking The University of Florida As an Example, Higher Education Exploration, 9, 56 (2015)

2. L.L. Jia, Analysis on the Long-term Mechanism of Internal Quality Assurance of First-class Undergraduate Teaching, Modern Education Management, 8, 77 (2017)

3. J. Zhang, Production of Concept and Innovative Design Methods:Promoting Design Teaching with International Design Competition, ZHUANGSHI, 10, 108 (2017)

4. http//www.cmu.edu ( webpage checked 20/08/2016)

5. http://www.cardesignevents.com (webpage checked 20/01/2018)

6. B.Y. Chen, Q. Liu, Studio Startup Education Mode:Connotation, Superiority and Prospect, University Education Science, 1, 98 (2017) 